\title{
EFFECT OF VAM FUNGI ON PHYTOCHEMICAL AND ANTIBACTERIAL ACTIVITY IN SOLANUM SURATTENSE L.
}

\section{O.N.Shanmugapriya and S.Priya*}

P.G and Research Department of Microbiology, S.T.E.T. Women's College, Mannargudi, T.Nadu, India

P.G Department of Biotechnology, S.T.E.T. Women's College, Mannargudi, T.Nadu, India Corresponding Author: piri_333@yahoo.co.in, +91 9787392903

\section{ABSTRACT}

In this study six fungal species were isolated from soil samples. Among the six species Glomus fasiculatum and Gigaspora marigarita noted in dominant level. So both are used as bioinoculant and were mass multiplied in onion plant by pot culture. After pot culture, biochemical and antibacterial activity were analysed from the treated plant Solanum surattense. In the phytochemical analysis falvonoids, tannins, terpenoids, cardiac glycosides and saponins were noted. Antibacterial activity of ethanolic extract of Solanum surattense against clinical isolates were analyzed and show the more activity noted in K.pneumoniae when compared with Bacillus subtilis, Streptococcus pyogens, E.coli respectively.

Key words: Phytochemical, bioinoculant, rhizosphere and Arbuscular mycorrhizae

\section{Council for Innovative Research}

Peer Review Research Publishing System

Journal of Advances in Natural Sciences

\author{
Vol. 3, No. 1 \\ editorjansonline@gmail.com




\section{INTRODUCTION}

Soil microorganisms play an important role in soil fertility, not only because of their ability in induces biochemical transformation but also of their importance as a source and store house for mineral nutrients (Smith and Read 1997. Several groups of microorganisms have the potential to enhance growth and improve the health of the plants. Various soil microbes perform specific functions such as biological nitrogen fixation, nitrification, and denitrification, phosphate solubilization and mobilization, cellulose and lignin decomposition and production of growth promoting hormones in the rhizosphere region of the plants.

Arbuscular mycorrhizae (AM) fungi are symbiotic associations formed between plants and soil fungi that benefit both partners. Arbuscular mycorrhizae (AM) fungi occupy a unique ecological position and are the most prevalent type (Romero et al., 2005). AMF is a potent biofertilizer, nutrient remedifier, eco-friendly and used in agriculture forestry and horticulture.

Biodiversity richness of plants species has long been of interest, but less is known about the richness of AMF in rhizosphere soils with which plants are associated. Although the role of AM fungi in nutrient uptake and plant growth is well documented, the use of selected AMF to improve the growth and productivity of fodder crops has been limited (Singh and Adholeya., 2002).

Occurrence of VAM fungi in medicinal plants have been reported by several workers. Medicinal plants in India were originally reported to be non-mycorrhizal, probably due to the presence of various secondary metabolites (Mohankumar and Mahadevan, 1984). In this present study, the isolation of VAM fungi from soil and dominant species were inoculated in to Solanum surattense by pot culture. The phytochemical and antibacterial activity of Solanum surattense against clinical isolates.

\section{MATERIALS AND METHODS \\ Collection of soil sample}

The soil samples were collected from local area of Thanjavur District at a depth of $0-30 \mathrm{~cm}$ as per the procedure adopted by Dickman et al., (1984). The samples collected in sealed plastic bags and stored at 5-10 ${ }^{\circ} \mathrm{C}$.

\section{Isolation and identification of VAM fungal spores}

AM fungal spores were isolated by a modified wet sieving and decanting techniques (Gerdemann and Nicolson, 1975) in soil samples. The morphology of spores and sporocaps of AM fungi were observed and their characters were used for identification using synoptic key of Morton and Benny (1990).

\section{Mass multiplication of AM fungi in the root of Onion}

The isolated AM fungi spores were multiplied in the specific host plant for inoculums preparation. Six native AM fungal species were isolated from the soil sample, among them two dominant native AM fungi species were selected for mass multiplication in the roots of onion to prepare the inoculums for further studies.

\section{Inoculum production}

The inoculums production was carried out in the lab condition by the funnel culture technique and pot culture method. The percentage of AM fungi colonization was determined and the recorded data were statistically analyzed. Healthy and viable seeds of Solanum surattense were procured from Tamil nadu Agricultural University, Coimbatore. The seeds were surface sterilized with $0.1 \%$ mercuric chloride and then sown in the sterilized soil bed (nursery) separately. The seedlings were grown in the seed bed for 25 days. Later the seedlings were transplanted to these pots (three seedlings per pot) separately for each crop. The experiments were carried out separately for each test plant in randomized complete block design with five replications.

\section{Root harvesting}

After eight weeks of planting the roots were harvested from treated with Glomus fasiculatum and Gigaspora marigarita and washed free of soil.

\section{Determination of percentage of VAM fungi infection in roots}

Vesicular Arbuscular Mycorrhizal association in the root samples of each specimens were examined and the percentage of infection were calculated by (Philips and Hayman,1970).

No. of positive segments

Percentage of infection $\quad=\quad$ Total number of segments analyzed 


\section{Analysis of phytochemical constituents and antibacterial activity of Solanum surattense}

\section{Phytochemical screening}

Chemical tests were carried out on the aqueous extract and on the powdered specimens using standard procedures to identify the constituents as described by (Sofowara, 1993).

\section{Antibacterial activity}

The antibacterial activity was carried out by the disc diffusion technique. The sterile nutrient agar plates were prepared and the test organisms like Bacillus subtilis, Streptococcus pyogens, E.coli and Klebsiella pneumonia spread over the nutrient agar plates by using sterile cotton buds separately. After the bacterial lawn each plant extract disc were placed on nutrient agar medium with equal distance, and control discs were also placed. All the plates were incubated at $37^{\circ} \mathrm{C}$ for $24 \mathrm{hrs}$. After incubation the plates were observed for inhibitory zones.

\section{RESULT AND DISCUSSION}

Six native AM fungi spores were isolated from soil samples which were identified, such as Glomus fasiculatum, Glomus aggregatum, Glomus deserticola, Acaulospora delegate, glomus gesporum and Gigaspora margarita. There have been phenomenol increases of interest on AMF in recent years leading to numerous surveys for enumerating and assessing AMF species and their colonization of host plants in different cultivated and non-cultivated soils (Selvaraj, 1989).

Occurrence of AMF is well documented in a wide range of natural ecosystem and cultivated field soils. The role of AMF in the improvement of plant growth and yield of crop plants and its importance in agriculture is well documented (Bagyaraj, 1991). However, very little information is available regarding their occurrence if fodder crops. Hence, it is necessary to understand the mycorrhizal association and diversity if fodder crops for their wise management.

In this study, Glomus fasiculatum and Gigaspora margarita spores were multiplied in onion plant (Allium cepa L.). The plants were used as the host plant for AM fungal inoculums production. The growth response and mycorrhizal development of onion plants raised in sand soils were assessed for the impact of inoculation with different native AM fungi. Onion plants varied in response to inoculation with different native AM fungi. Inoculated plants generally had greater plant height, biomass production in shoot, bulb and root uptake compared to uninoculated control.AM fungi are known to improve plant growth mainly through increased P-uptake and nutrients. Jeffries (1987) reported that species and strains of AM fungi have different to the extent to which they increase nutrient uptake and plant growth.

Solanum surattense taken for experimental plant for AM fungal species inoculums and analysis the various parameters. The phytochemical screening (table-1) of the Solanum surattense plant extract contains tannin, saponin, falvonoids, terpenoids and cardiac glycosides. These were screened based on the development colours. Contents of total phenols and ortho-hydroxyl phenols were also increased significantly in the roots and leaves of all the three fodder crops of mycorrhizal inoculated plants. The increase in total phenols in inoculated plants could be attributed to triggering of pathways of aromatic biosynthesis (Mohankumar and Mahadevan, 1984)

Antibacterial activities of four different experimental ethanolic plant extract (table-2) of Solanum surattense were analyzed against clinical isolates. Among the isolates maximum antibacterial activities were observed in combined VAM fungi inoculated plant extract against all the organisms. Among the four test organisms more activity noted in K.pneumoniae when compared with the others. Traditionally Solanum surattense had been used to treat many disease caused by bacteria (Duke and Beckstrom-sternberg, 2002).

\section{CONCLUSION}

The study concludes that the Glomus fasiculatum and Gigaspora margarita used as bioinoculant to improve the plant growth and phytochemical compounds. The plant (Solanum surattense) extracts used as antibacterial agent for destroying the pathogenic organisms and also used to curing number of diseases.

\section{REFERENCES}

1. Smith S.E., and Read D.J., 1997. Mycorrhizal symbiosis. $2^{\text {nd }}$ edition.Academic press, San Diego.665.

2. Romero C.D., Chopin S.F., Buck. L., Martinz E., Galsia M., Bixby L., 2005. Antibacterial properties of common herbal remedies of the south west. J. Ethanophar., 99: 253-259.

3. Singh C.S., and Adholeya., 2002. Mass inoculums production of vesicular arbuscular mycorrhizae. Effect of various bacteriological media and fertilizer solutions. Miocr. Res., 149:27-9.

4. Mohankumar and Mahadevan, 1984. Changes in nitrate reductase and glutamine synthetase activity in Zizipus mauitiania by different AM fungi.Curr. Sci., 68(2):1144-1146.

5. Dickman L.A., Liberta A.E. and Erson R.C. 1984. Ecological interaction of little bluenstem and vesicular arbuscular mycorrhizal fungi.Canad. J .Bot., 71:1625-1630. 
6. Gredman J.W., and Nicolson T.H., 1975. Spores of mycorrhizal endogene extracted from soil by wet sievinf technique. Trans.Br. Mycol., 46:248-252.

7. Morton J.B., and Benny G.L., 1990. Reised classification of arbuscular mycorrhizae fungi, a new oder, two sub oders, glominane and gigasporinae and two new families, Acaulosporaceae and Gigasporaceae with an abundance of Glomaceae.Mycotaxon., 37:472-479.

8. Phillips J., and Hayman., 1970. Improved procedure for clearing roots and staining parasitic VAM fingi for rapid assessment of infection. Trans. Biol., Mycol., 5:158-61.

9. Sofawara L.A., 1993. Medicinal plants and traditional medicine in Africa spectrum Books Ltd,Ibaban Harborne,5571.

10. Selvaraj T., 1989. Studies on arbuscular mycorrhizae of some crop and medicinal plants. Ph.D. thesis, Bharathidasan university, Thiruchirappali, Tamil nadu,India, pp.120.

11. Bagyaraj D.J., 1991. Ecology of vesicular arbuscular mycorrhizae. In handbook of applied mycology soil and plants, New York, I:1-34.

12. Jeffries 1987. Use of mycorrhizae in agriculture.Cri.Rev.Biotech., 5: 319-357.

13. Duke J., and Beckstrom-sternberg S.M., 2002. Phytochemical databse, ARS Agricultural Research Ceter, Belts ville, Maryland.p-54.

Table-1: Photochemical analysis of Solanum surattense

\begin{tabular}{|l|l|c|}
\hline S.No. & Phytochemical compounds & Result \\
\hline 1 & Tannis & + \\
\hline 2 & Falvanoids & + \\
\hline 3 & Steroids & + \\
\hline 4 & Terpenoids & + \\
\hline 5 & Cardiac glycosides & + \\
\hline 6 & Saponin & + \\
\hline
\end{tabular}

Table-2: Antibacterial activity of Solanum surattense against clinical isolates

\begin{tabular}{|l|l|l|l|l|l|}
\hline \multirow{2}{*}{ S.No. } & Sample & \multicolumn{2}{l|}{ Zone of inhibition (mm in diameter) } \\
\cline { 3 - 6 } & & B.subtilis & S.pyogens & E.coli & K.pneumoniae \\
\hline 1 & Control (without AM fungi) & $6 \pm 0.24$ & $6.5 \pm 0.211$ & $8 \pm 0.31$ & $8.4 \pm 0.14$ \\
\hline 2 & $\begin{array}{l}\text { Inoculated with Glomus } \\
\text { fasiculatum }\end{array}$ & $8 \pm 0.10$ & $10 \pm 0.10$ & $10 \pm 0.11$ & $10 \pm 0.28$ \\
\hline 3 & $\begin{array}{l}\text { Inoculated with Gigaspora } \\
\text { margarita }\end{array}$ & $10 \pm 0.12$ & $9 \pm 0.13$ & $8 \pm 0.22$ & $11 \pm 0.53$ \\
\hline 4 & $\begin{array}{l}\text { Inoculated with combined } \\
\text { Glomus fasiculatum and } \\
\text { Gigaspora margarita }\end{array}$ & $10 \pm 0.14$ & $10 \pm 0.33$ & $11 \pm 0.93$ & $12 \pm 0.42$ \\
\hline
\end{tabular}

